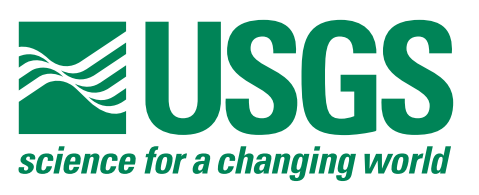

\title{
A USGS Study of Talc Deposits and Associated Amphibole Asbestos Within Mined Deposits of the Southern Death Valley Region, California
}

By Bradley S. Van Gosen, Heather A. Lowers, and Stephen J. Sutley

This report is preliminary and has not been reviewed for conformity with U.S. Geological Survey editorial standards or with the North American Stratigraphic Code

Any use of trade, firm, or product names is for descriptive purposes only and does not imply endorsement by the U.S. Government

U.S Geological Survey Open-File Report 2004-1092

U.S. Department of the Interior

U.S. Geological Survey 


\section{INTRODUCTION}

The study described in this report was conducted under National Park Service Scientific Research and Collecting Permit \# DEVA-2003-SCI-0014 (with park-assigned study identification \# DEVA-00075). The study investigated the mineralogy of talc deposits mined during the $20^{\text {th }}$ century in several mountain ranges that surround the southern part of Death Valley, California (fig. 1). The permit authorized the collection and analyses of talc-rich and related rocks from former talc mining properties within Death Valley National Park (DVNP). The permit stipulated that, "In addition to the above permitted sample collections, brick-sized samples of talc will be taken from each mine area for the park museum study collection". This report describes the mineralogy and chemical composition of eight brick-sized rock samples that were contributed to the DVNP museum collection, which were collected by the lead investigator (Bradley Van Gosen) in June of 2003.

\section{BACKGROUND}

Possibly the best examples in the U.S. of talc ore bodies formed by contact metamorphism are 45 deposits that have been mined and prospected in the southern Death Valley region, California (fig. 1). Twenty of these mines and prospects are now inside the boundaries of DVNP. The talc deposits are consistently associated with a carbonate horizon of the Crystal Spring Formation where it was intruded by regionally persistent gabbro sills. This sill-carbonate rock contact zone contains talc-tremolite rock, which has been mined from 1910 to present. Talc mining ended in 1988 in the mining claims that are now within DVNP. Active mining of talc appears to continue on a small scale in the Kingston Range, east of DVNP. The Death Valley talc has been used mainly in the manufacture of ceramic wall tiles and as an extender in paints (Wright, 1957; Evans and others, 1976).

The talc-tremolite mines of the region lie in mountain ranges that surround southern Death Valley; the talc-bearing belt is about $120 \mathrm{~km}$ long by $24 \mathrm{~km}$ wide. The geology of the region, the mine sites, and their early mining history are well described by Wright (1968). These deposits are geologically rather similar across the region (Wright, 1957, 1968; Evans and others, 1976). Thick mafic (gabbroic) sills, mostly medium-grained, intruded a siliceous (cherty) dolomitic member of the Proterozoic-age Crystal Spring Formation, forming friable talctremolite-rich rock along the sill-carbonate contact zones. The gabbro sills were emplaced during the Mesoproterozoic, based on age determinations by the U-Pb method from baddeleyite crystals in two sills (1087 \pm 3 and $1069 \pm 3 \mathrm{Ma}$, Heaman and Grotzinger, 1992). These ages indicate that the associated talc-tremolite deposits are Mesoproterozoic in age.

The talc-tremolite replacement bodies are typically from 150 to 1,500 m long and 3 to about $30 \mathrm{~m}$ thick (Wright, 1968). Stratigraphic intervals within the replacement deposits can vary vertically and laterally from talc-rich, tremolite-poor to tremolite-rich, talc-poor (Wright, 1968). Our petrographic observations found only sporadic evidence of talc replacing amphibole. More petrographic study is necessary to determine if the intergrowths of platy talc and acicular amphiboles in these deposits formed by coeval or discontinuous crystallization.

In March 2002, the lead author sampled talc-rich rock and associated rocks in road cuts, and abandoned mine dumps and open pits in the Alexander Hills and Kingston Range, near Tecopa and east of DVNP (fig. 1). Our mineralogical analyses of the talcose rock revealed that it contains a considerable proportion of tremolite, and locally much of this tremolite is asbestiform. The geologic literature describing the talc deposits within DVNP (Wright, 1957, 1968; Norman and Stewart, 1951; Franklin, 1965; Papke, 1975; Evans and others, 1976) 

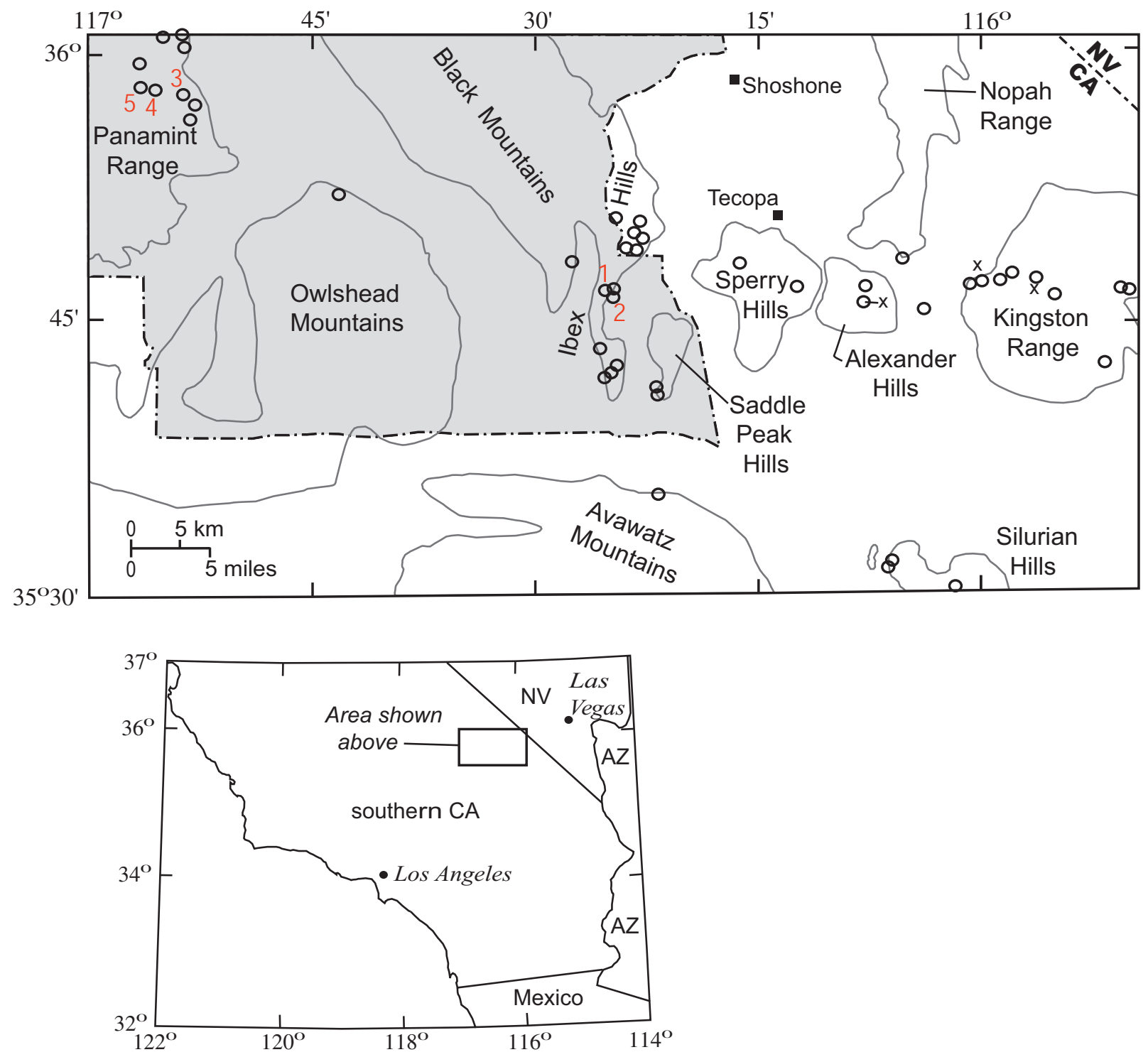

Figure 1. Generalized map of southern Death Valley National Park (shaded) and surrounding area, southern California, showing the mountain ranges that contain talctremolite mines, prospects, and occurrences (open circles). Sites sampled by this study east of the Park are shown by three small x's in the Alexander Hills and Kingston Range. Rock samples contributed to the Death Valley National Park museum study collection were collected at the following talc mines (shown by red labels):
1. Moorehouse (Ibex) mine
4. Number 3 workings
2. Pleasanton mine
5. White Point workings

3. Grantham (Big Talc) mine 
suggests these deposits have similar geologic characteristics to the asbestos-bearing talctremolite deposits mined outside the park (Wright, 1957, 1968; Wright and others, 1953). However, the geologic descriptions of the park's talc-tremolite deposits lack the microscopic and sub-microscopic characterization needed to evaluate their asbestos potential. The USGS proposed to study and hand sample the historic talc mines of DVNP to carefully characterize their amphibole content, for comparison and (or) contrast to similar deposits in the region.

The largest talc-mining district of the Death Valley area, and likely the largest producer, was the Grantham-Warm Spring district, which consisted of a series of adits and open pits spread out for just over 2 miles (3.2 km) along Warm Spring Canyon in southwestern Death Valley National Park. The second largest mine complex, consisting of adits and large open pits, was the Western-Acme mine in the Alexander Hills southeast of Tecopa. The majority of the USGS sampling efforts in June of 2003 focused on these two districts (fig. 1).

\section{USGS STUDY OF TALC DEPOSITS OF THE DEATH VALLEY REGION}

To build upon the sample set of March 2002, in June of 2003, the lead author collected hand samples of talc ores and associated rocks from several talc mines in Warm Spring Canyon and the Ibex Hills, located in southern parts of Death Valley National Park (fig. 1). On this same field trip, samples were collected from the abandoned Acme mine in the Alexander Hills east of the park. Samples were collected from dumps, pit walls, ore chutes, and nearby outcrops. Subsequent analyses of the samples were performed at USGS laboratory facilities in Lakewood, Colorado. The analytical data from this study have contributed considerable information about the mineralogy of the talc deposits mined in the southern Death Valley region.

\section{Analytical Methods}

Splits of the samples were analyzed by x-ray diffraction (XRD) and examined by scanning electron microscopy (SEM) accompanied by energy-dispersive spectrometry analyses (EDS).

Dust coating the inside of each plastic sampling bag was examined using a JEOL 5800LV SEM equipped with an Oxford ISIS EDS system with ultra-thin window detector. The EDS provided semi-quantitative chemical data that was reduced using the Oxford ISIS standardless software with the ZAF correction procedure selected. Analyses were performed on single, isolated structures, not on particles that lay across other mineral particles. The operating conditions of the instrument were $15 \mathrm{kV}, 0.5-3 \mathrm{nA}$ (cup), and approximately $30 \%$ dead time. These conditions produce an excitation volume of $\sim 2 \mu \mathrm{m}$ in typical amphibole particles.

Samples for XRD analyses were pulverized and mechanically split. The minerals identified by XRD in the samples were categorized as major, minor, and trace mineral constituents of the analyzed split. "Major" minerals are estimated to comprise $>25 \mathrm{wt}$. \% (weight percent) of the sample, "minor" minerals form 5-25 wt. \% of the sample, and "trace" 1 minerals form $<5$ wt. $\%$ of the sample. These estimates were based on the experience of the XRD operator with his instrumentation and its data output. The pulverized splits examined by this study provide snapshots of the mineralogy and variability in the sample. However, quantitative estimates of the minerals found should not be interpreted from the XRD results shown in this report.

\footnotetext{
${ }^{1}$ Note that our use of the term "trace" is not comparable with the its usage in many environmental, regulatory, or health contexts, where it often refers to quantities of $<1$ weight percent.
} 
The XRD technique can identify the amphibole minerals as members of a particular amphibole series, such as the tremolite-actinolite-ferroactinolite series, but XRD is usually not able to determine the specific amphibole species. Analyzing a sample by XRD, and supplementing this data with SEM-EDS study of the sample, allows us to classify the amphibole particles with reasonable certainty. The amphibole nomenclature used in this study follows the recommendations of Leake and others (1997).

Splits of the rocks samples were analyzed by wavelength-dispersive X-ray fluorescence spectrometry (WDXRF) to determine their major-element composition. The WDXRF analyses were conducted by Joseph E. Taggart in USGS laboratories, Lakewood, Colorado. See Taggart and Siems (2002) for a description of the USGS's WDXRF method.

\section{Summary of Study Results}

The study results, summarized briefly here, are presented in more detail in an article to be published in the journal Environmental Geology (Van Gosen and others, 2004).

Our sampling and analytical results suggest talc is the predominant ore mineral in the mined deposits of the southern Death Valley region; however, as noted in earlier publications, tremolite is typically a major constituent of these deposits. Other major to minor components of the ore material include calcite, dolomite, quartz, phlogopite, magnesiohornblende, and sepiolite.

The tremolite particles in the Death Valley ores, as is typical in tremolitic talc deposits, range in habit from blocky to prismatic to acicular to asbestiform, commonly within a single sample (fig. 2). Scattered amphiboles in the Death Valley talc deposits occur in asbestiform habits, as bundles of fibers and loose fibers. Our examination by SEM-EDS of talc ore samples from the southern Death Valley mines found asbestiform amphiboles in most of the samples. Whereas amphibole particles with prismatic to acicular habits were most common, particles with asbestiform habits (as defined in Appendix A of Perkins and Harvey, 1993) were locally numerous.

In addition to the previously recognized tremolite, EDS analyses indicated that a number of the asbestiform particles in talc ores from several mines have compositions consistent with the sodic-calcic amphiboles richterite and winchite (Leake and others 1997).

Quantifying the abundance of "asbestos" material within the Death Valley talc ores was beyond the scope of this study. Our SEM-EDS analysis of the friable material (dust) caused by light handling of the ore samples suggests that prismatic particles are the most common amphibole habit in the talcose rocks (fig. 2). Blocky, prismatic, and acicular examples of the amphiboles in each sample yielded compositions similar to those measured in the fibrous particles. No obvious correlation between particle composition and morphology was foundtremolite, richterite, and winchite compositions were found in crystals that range from nonfibrous to highly fibrous in habit.

We emphasize that our sampling and SEM-EDS studies of these talc deposits were reconnaissance in fashion. Importantly, asbestiform amphiboles in the ore samples were often encountered in SEM scans of the ore material; asbestiform particles locally occur in amounts as high as one percent by volume (visual estimate), but typically less, in ore samples.

\section{SAMPLES CONTRIBUTED TO THE MUSEUM STUDY COLLECTION}

Eight brick-sized rock samples collected during the USGS study of Death Valley talc deposits were contributed to the DVNP museum study collection. The donated samples represent the talc ores and igneous intrusive rocks exposed at former talc mines in southern areas 
of DVNP (fig. 1). These samples came from two mines in the Ibex Hills - the Moorehouse (Ibex) and Pleasanton mines - and three mines in Warm Spring Canyon of the southern Panamint Range - the Grantham (Big Talc) mine, the Number 3 workings, and the White Point workings (fig. 1, tables 1 and 2). The tables that follow summarize the results of laboratory analyses of the museum collection rock samples, including:

- the fibrous amphibole content of the friable material (dust) released from light handling of the talc samples (table 3);

- $\quad$-ray diffraction analyses of the talc samples (table 4);

- SEM-EDS analyses of representative fibrous amphibole particles in the talc samples (table 5); and

- whole-rock major-element chemical analyses of both talc and gabbro samples (table 6). 

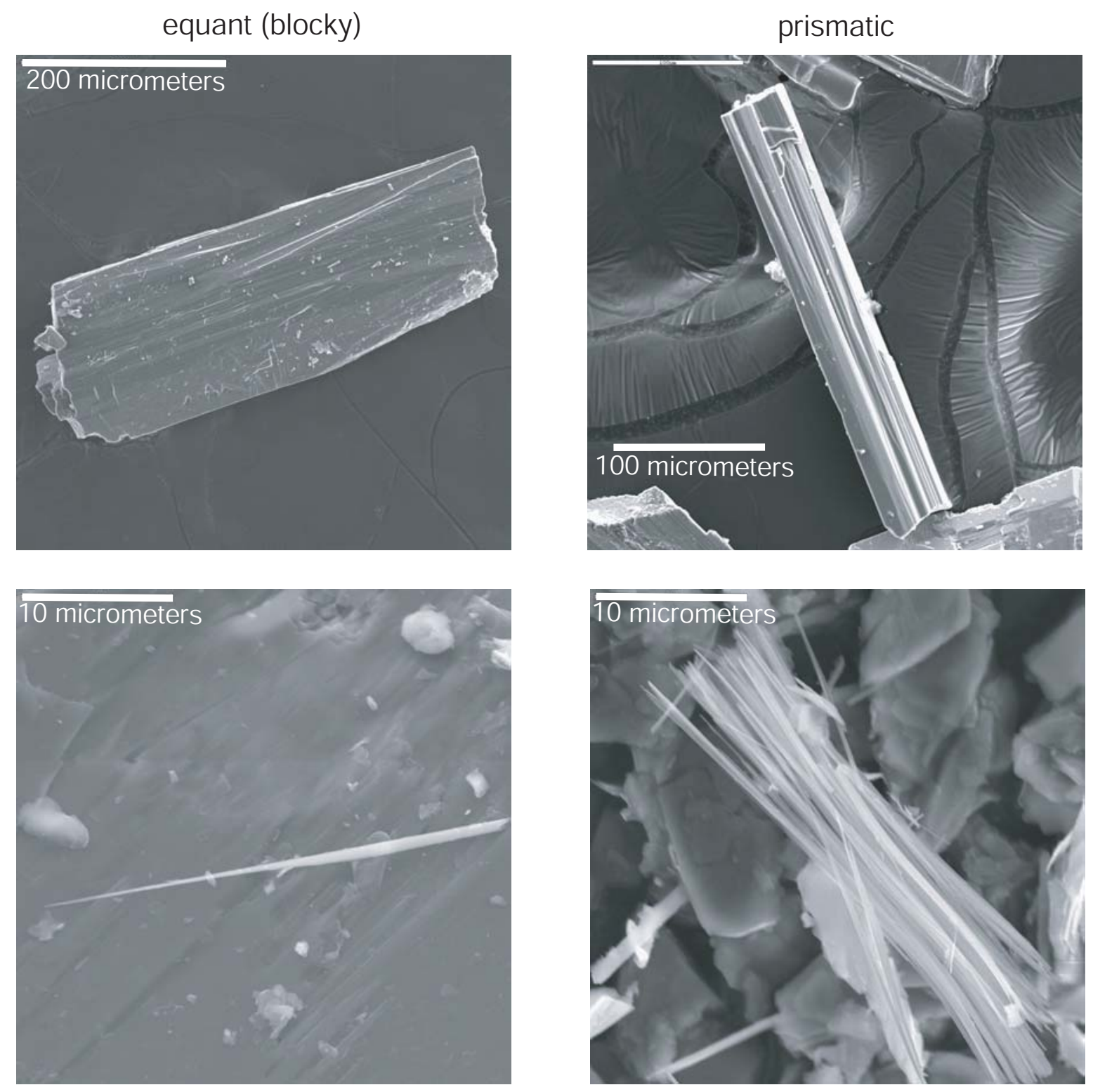

acicular

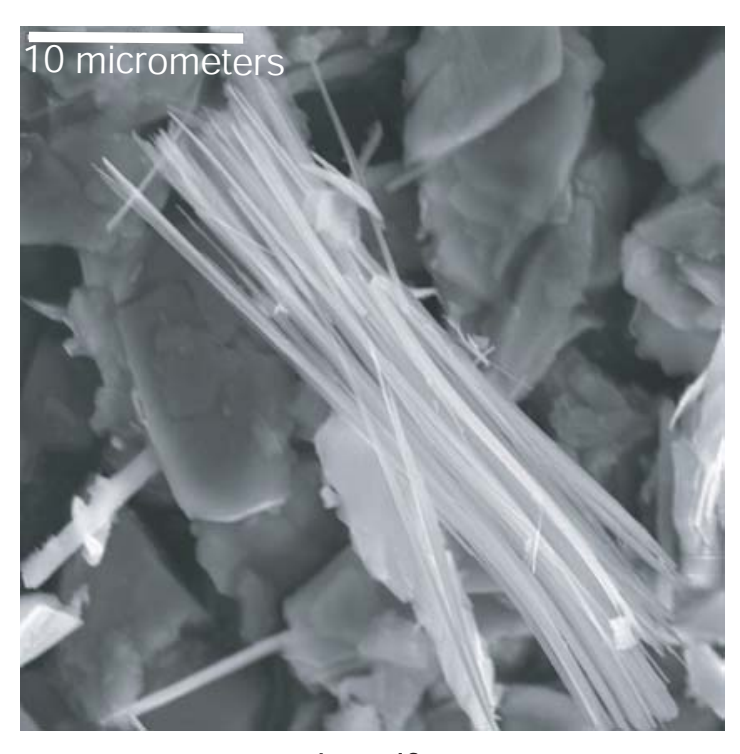

asbestiform

Figure 2. SEM photomicrographs that show the typical range of amphibole morphologies within the talcose replacement deposits of the southern Death Valley region. Our reconnaissance study suggests that prismatic shapes are the most common amphibole habit in these talc deposits. Amphibole compositions consistent with tremolite, richterite, and winchite were found in particles of all of these habits (based upon semi-quantative SEM-EDS analyses). Our crystal morphology nomenclature is consistent with the recommendations of Campbell and others (1977) and Perkins and Harvey (1993). 
Table 1. List of the talc mines where the 8 DVNP museum study samples were collected. The latitude, longitude values were measured by GPS using the 1927 North American datum, CONUS. The references listed provide information on the geology, history, workings, and (or) talc reserves of the mining property.

\begin{tabular}{|l|l|l|l|}
\hline Talc mine (Sample site) & Location & Latitude, Longitude & References \\
\hline $\begin{array}{l}\text { Moorehouse (Ibex) mine, } \\
\text { Ibex Hills }\end{array}$ & $\begin{array}{l}\text { NW1/4 of section 35, } \\
\text { T. 191/2 N., R. 5 E. }\end{array}$ & $35.7802,-116.4160$ & Wright (1968, p. 52-55) \\
\hline $\begin{array}{l}\text { Pleasanton mine, } \\
\text { Ibex Hills }\end{array}$ & $\begin{array}{l}\text { NE1/4 of section 35, } \\
\text { T. 191/2 N., R. 5 E. }\end{array}$ & $35.7775,-116.4110$ & $\begin{array}{l}\text { Wright (1968, p. 57-60); Evans and } \\
\text { others (1976, p. 45-46) }\end{array}$ \\
\hline $\begin{array}{l}\text { Grantham (Big Talc) mine, } \\
\text { Warm Spring Canyon }\end{array}$ & $\begin{array}{l}\text { SW1/4 of section 32, } \\
\text { T. 22 N., R. 1 E. }\end{array}$ & $35.9611,-116.8955$ & $\begin{array}{l}\text { Norman and Stewart (1951, p. 126- } \\
\text { 127); Franklin (1965); Wright } \\
(1968, \text { p. 48-52); Papke (1975); } \\
\text { Evans and others (1976, p. 36-43) }\end{array}$ \\
\hline $\begin{array}{l}\text { Number 3 workings, } \\
\text { Warm Spring Canyon }\end{array}$ & $\begin{array}{l}\text { NE1/4 of section 5, } \\
\text { T. 23 S., R. 47 E. }\end{array}$ & $35.9663,-116.9213$ & $\begin{array}{l}\text { Wright (1968, p. 52); Evans and } \\
\text { others (1976, p. 38-40) }\end{array}$ \\
\hline $\begin{array}{l}\text { White Point workings, } \\
\text { Warm Spring Canyon }\end{array}$ & $\begin{array}{l}\text { NW1/4 of section 5, } \\
\text { T.23 S., R. 47 E. }\end{array}$ & $35.9684,-116.9283$ & Wright (1968, p. 52) \\
\hline
\end{tabular}

Table 2. Descriptions of the 8 DVNP museum study collection samples and the sampling site.

\begin{tabular}{|c|l|l|}
\hline $\begin{array}{c}\text { Sample site, } \\
\text { Sample number }\end{array}$ & Rock type & Sample site description \\
\hline Moorehouse (Ibex) mine & $\begin{array}{l}\text { Laminated, folded } \\
\text { talc schist }\end{array}$ & A mine dump located just outside of an adit entrance (fig. 3). \\
\hline 30CDV03 & Laminated talc schist & $\begin{array}{l}\text { A mine dump located just outside of an adit entrance (fig. 3). Figure } \\
\text { 4 shows an example of fibrous amphiboles found in talc ore from } \\
\text { this sample site. }\end{array}$ \\
\hline Pleasanton mine & $\begin{array}{l}\text { Fine- to medium- } \\
\text { grained gabbro }\end{array}$ & $\begin{array}{l}\text { Sill in the hanging wall of the deposit; sample grabbed from an } \\
\text { outcrop near the head frame of the mine (fig. 5) }\end{array}$ \\
\hline 36ADV03 & $\begin{array}{l}\text { A mine dump located near the head frame of the mine (fig. 5) } \\
\text { talc schist }\end{array}$ \\
\hline 36BDV03 & $\begin{array}{l}\text { Waminated, folded } \\
\text { schist }\end{array}$ \\
\hline Grantham (Big Talc) mine \\
\hline 21CDV03 & $\begin{array}{l}\text { Fine- to medium- } \\
\text { grained gabbro }\end{array}$ & $\begin{array}{l}\text { S talc ore body, near its contact with the host dolostone, at an } \\
\text { outcropping next to an adit of the Grantham mine (fig. 6). } \\
\text { example of the fibrous amphiboles found in talc deposits that overlie } \\
\text { sills at the Grantham mine. }\end{array}$ \\
\hline 21GDV03 & The middle of a partially reclaimed open pit \\
\hline Number 3 workings & Talc rock & A mine dump near the haulage adit of the White Point mine (fig. 9) \\
\hline 23DDV03 & Talc rock
\end{tabular}


Table 3. Summary of the fibrous amphibole content in the dusts formed by handling of the talc samples. The analyses were conducted by scanning electron microscopy accompanied by energy-dispersive spectrometry (SEM-EDS). The use of terms "asbestos" and "asbestiform" used in this report follow asbestos guidelines put forth by the Occupational Safety and Health Administration (1992) and the U.S. Environmental Protection Agency (Perkins and Harvey, 1993) - these fibrous amphiboles are more than 5 micrometers in length and less than 1 micrometer in width, have aspect (length:width) ratios of 20:1 or higher, sometimes occur in bundles with splayed ends, and display curvature (fig. 4).

\begin{tabular}{|c|c|}
\hline $\begin{array}{l}\text { Sample site, } \\
\text { Sample number }\end{array}$ & SEM-EDS analytical results \\
\hline \multicolumn{2}{|c|}{ Moorehouse (Ibex) mine } \\
\hline 30CDV03 & $\begin{array}{l}\text { A number of asbestiform amphibole particles were found in the sample, locally } \\
\text { forming up to } 1 \% \text { of the volume, but usually less. }\end{array}$ \\
\hline 30DDV03 & $\begin{array}{l}\text { A number of asbestiform amphibole particles were found in the sample, locally } \\
\text { forming up to } 1 \% \text { of the volume, but usually less. }\end{array}$ \\
\hline \multicolumn{2}{|l|}{ Pleasanton mine } \\
\hline 36BDV03 & $\begin{array}{l}\text { Only a few asbestiform amphibole particles were found in this sample, which were } \\
\text { widely scattered. Another sample of talcose rock collected from the Pleasanton } \\
\text { mine, grabbed near the contact of the ore body with the host dolomite (fig. 5), was } \\
\text { found to contain a number of asbestiform amphibole particles. }\end{array}$ \\
\hline \multicolumn{2}{|c|}{ Grantham (Big Talc) mine } \\
\hline 21CDV03 & $\begin{array}{l}\text { Only a few asbestiform amphibole particles were found in this sample, which were } \\
\text { widely scattered. However, several other samples of the Grantham mine talc ore } \\
\text { were found to contain numerous amphibole fibers (fig. 8), locally comprising up to } \\
1 \% \text { of the volume, but usually less. }\end{array}$ \\
\hline \multicolumn{2}{|l|}{ Number 3 workings } \\
\hline 23DDV03 & $\begin{array}{l}\text { A number of asbestiform amphibole particles were found in the sample, locally } \\
\text { forming up to } 1 \% \text { of the volume, but usually less. }\end{array}$ \\
\hline \multicolumn{2}{|c|}{ White Point workings } \\
\hline 23EDV03 & $\begin{array}{l}\text { The residues of this sample, and several other talc samples from this deposit (fig. 10), } \\
\text { were found to contain a number of asbestiform amphibole particles (fig. 11), locally } \\
\text { forming up to } 1 \% \text { of the volume, but usually less. }\end{array}$ \\
\hline
\end{tabular}

Table 4. Results of x-ray diffraction analyses on the talc rock samples donated to the DVNP museum study collection. "Major" minerals are estimated to comprise $>25 \mathrm{wt}$ \% of the sample, "minor" minerals form 5-25 wt. \% of the sample, and "trace" minerals form $<5$ wt. $\%$ of the sample (see text). The x-ray diffraction technique cannot definitively distinguish individual species within the amphibole mineral group.

\begin{tabular}{|l|l|l|l|}
\hline Sample No. & Major & Minor & Trace \\
\hline 30CDV03 & calcite, talc & & muscovite, calcic amphibole \\
\hline 30DDV03 & talc & calcite & muscovite or phlogopite, quartz \\
\hline 36BDV03 & talc, dolomite & quartz & muscovite \\
\hline 21CDV03 & talc & calcite & calcic amphibole, vermiculite \\
\hline 23DDV03 & talc & & calcic amphibole, vermiculite \\
\hline 23EDV03 & calcic amphibole, talc & dolomite & muscovite, quartz, calcite, vermiculite \\
\hline
\end{tabular}


Table 5. SEM-EDS analyses of representative fibrous amphibole particles in the talc rock samples contributed to the DVNP museum study collection. Cation ratios were calculated from the chemical analyses by stoichiometry using 23 oxygen atoms for amphibole; $(\mathrm{OH}+\mathrm{F}+\mathrm{Cl})$ was assumed to be 2 . The EDS technique cannot distinguish between the oxidation states of $\mathrm{Fe}\left(\mathrm{Fe}^{3+}\right.$ versus Fe $\left.\mathrm{Fe}^{2+}\right)$. The amphibole was identified by choosing the most likely amphibole species based on the semi-quantitative EDS data. Amphibole nomenclature used is based on the recommendations of Leake and others (1997). bdl; below the detection limit of the EDS technique. tr; trace (detectable, but not quantifiable). All Fe reported as FeO.

\begin{tabular}{|c|c|c|c|c|c|c|c|c|c|}
\hline Sample No. & 30CDV03 & $30 \mathrm{CDV} 03$ & 30CDV03 & 30DDV03 & 30DDV03 & 30DDV03 & 36BDV03 & 36BDV03 & 36BDV03 \\
\hline $\begin{array}{l}\text { Fiber shape } \\
\text { L x W ( } \mu \mathrm{m})\end{array}$ & $26.9 \times 1.7$ & $33.1 \times 2.4$ & $25.2 \times 1.8$ & $31.6 \times 1.4$ & $57.0 \times 2.1$ & $24.3 \times 0.1$ & $17.0 \times 0.6$ & $29.9 \times 0.5$ & $24.1 \times 1.0$ \\
\hline $\mathrm{SiO}_{2}$ & 59 & 60 & 60 & 58 & 60 & 59 & 58 & 58 & 59 \\
\hline $\mathrm{TiO}_{2}$ & $\operatorname{tr}$ & bdl & $\operatorname{tr}$ & $\operatorname{tr}$ & $\operatorname{tr}$ & bdl & 0.6 & 0.7 & $\operatorname{tr}$ \\
\hline $\mathrm{Al}_{2} \mathrm{O}_{3}$ & $\operatorname{tr}$ & bdl & bdl & 0.3 & bdl & 0.4 & 0.6 & 1.4 & 0.6 \\
\hline $\mathrm{FeO}$ & 2.3 & 2.5 & 2.9 & 3.6 & 1.7 & 1.3 & 1.6 & 0.8 & 2.1 \\
\hline MnO & 0.4 & bdl & $\operatorname{tr}$ & 0.3 & bdl & bdl & bdl & bdl & 0.7 \\
\hline $\mathrm{MgO}$ & 24 & 24 & 24 & 25 & 25 & 26 & 26 & 26 & 25 \\
\hline $\mathrm{CaO}$ & $\begin{array}{ll}6.6 \\
\end{array}$ & 6.4 & 6.2 & 6.1 & $\overline{6.4}$ & 5 & 5.5 & 3.4 & 4.2 \\
\hline $\mathrm{Na}_{2} \mathrm{O}$ & 5.5 & 5.3 & 5.3 & 5.9 & 4.7 & 7.1 & 6.2 & 6.4 & 7.8 \\
\hline $\mathrm{K}_{2} \mathrm{O}$ & 1.8 & 1.8 & 2.1 & 1.0 & 1.7 & 1.6 & 2.2 & 3.1 & 0.9 \\
\hline \multicolumn{10}{|c|}{ Calculated cation proportions } \\
\hline $\mathbf{S i}$ & 8.1 & 8.1 & 8.0 & 7.9 & 8.1 & 7.9 & 7.8 & 7.9 & 7.8 \\
\hline $\mathrm{Ti}$ & $\operatorname{tr}$ & bdl & $\operatorname{tr}$ & $\operatorname{tr}$ & $\operatorname{tr}$ & bdl & 0.1 & $\operatorname{tr}$ & $\operatorname{tr}$ \\
\hline $\mathbf{A l}$ & $\operatorname{tr}$ & bdl & bdl & 0.1 & bdl & $\operatorname{tr}$ & 0.2 & 0.1 & 0.1 \\
\hline $\mathbf{F e}$ & 0.3 & 0.3 & 0.3 & 0.2 & 0.2 & 0.4 & 0.1 & 0.2 & 0.2 \\
\hline $\mathbf{M n}$ & $\operatorname{tr}$ & bdl & $\operatorname{tr}$ & $\operatorname{tr}$ & $\mathrm{bdl}$ & bdl & bdl & bdl & $\operatorname{tr}$ \\
\hline $\mathbf{M g}$ & 4.7 & 4.8 & 4.9 & 5.1 & 5.0 & 5.0 & 5.2 & 5.0 & 5.2 \\
\hline $\mathrm{Ca}$ & 0.9 & 0.9 & 1.0 & 0.7 & 0.9 & 0.9 & 0.5 & 0.6 & 0.8 \\
\hline $\mathrm{Na}$ & 1.4 & 1.4 & 1.4 & 1.9 & 1.2 & 1.5 & 1.7 & 2.0 & 1.6 \\
\hline $\mathbf{K}$ & 0.4 & 0.3 & 0.3 & 0.3 & 0.3 & 0.2 & 0.5 & 0.1 & 0.4 \\
\hline $\begin{array}{l}\text { Probable } \\
\text { Amphibole }\end{array}$ & richterite & richterite & richterite & richterite & winchite & richterite & richterite & richterite & richterite \\
\hline
\end{tabular}


Table 5. Continued.

\begin{tabular}{|c|c|c|c|c|c|c|c|c|c|}
\hline Sample No. & 21CDV03 & 21CDV03 & 21CDV03 & 23DDV03 & 23DDV03 & 23DDV03 & 23EDV03 & 23EDV03 & 23EDV03 \\
\hline $\begin{array}{c}\text { Fiber shape } \\
\left.\text { L x W ( }{ }^{2}\right)\end{array}$ & $19.1 \times 0.8$ & $17.3 \times 1.3$ & $28.1 \times 1.0$ & $22.5 \times 1.5$ & $93.6 \times 1.0$ & $60.2 \times 1.7$ & $29.5 \times 1.2$ & $26.2 \times 0.9$ & $20.8 \times 1.7$ \\
\hline $\mathrm{SiO}_{2}$ & 59 & 61 & 61 & 62 & 60 & 61 & 60 & 61 & 60 \\
\hline $\mathrm{TiO}_{2}$ & bdl & bdl & bdl & bdl & bdl & bdl & $\operatorname{tr}$ & bdl & $\operatorname{tr}$ \\
\hline $\mathrm{Al}_{2} \mathrm{O}_{3}$ & 1.3 & bdl & 0.4 & $\mathrm{bdl}$ & 0.3 & $\operatorname{tr}$ & bdl & $\operatorname{tr}$ & $\operatorname{tr}$ \\
\hline $\mathrm{FeO}$ & 0.7 & bdl & 2 & bdl & $\operatorname{tr}$ & 0.6 & 0.3 & 0.6 & $\operatorname{tr}$ \\
\hline MnO & bdl & bdl & bdl & $\mathrm{bdl}$ & bdl & bdl & bdl & bdl & $\operatorname{tr}$ \\
\hline MgO & 26 & 26 & 26 & 26 & 27 & 25 & 27 & 27 & 26 \\
\hline $\mathrm{CaO}$ & 5.8 & 9.2 & 3.7 & 13 & 13 & 13 & 11 & 9.3 & 12 \\
\hline $\mathrm{Na}_{2} \mathrm{O}$ & 4.7 & 2.9 & 5.1 & bdl & $\mathrm{bdl}$ & bdl & 1.0 & 1.8 & 1.3 \\
\hline $\mathrm{K}_{2} \mathrm{O}$ & 1.7 & 1.2 & 2.3 & $\operatorname{tr}$ & $\mathrm{bdl}$ & 0.3 & 0.3 & 0.4 & 0.5 \\
\hline \multicolumn{10}{|c|}{ Calculated cation proportions } \\
\hline$\overline{S i}$ & 8.1 & 8.1 & 7.9 & 8.1 & 7.9 & 8.1 & 8.0 & 8.0 & 7.9 \\
\hline$\overline{\mathrm{Ti}}$ & bdl & bdl & bdl & bdl & bdl & bdl & $\operatorname{tr}$ & bdl & $\operatorname{tr}$ \\
\hline $\mathrm{Al}$ & 0.1 & bdl & 0.2 & bdl & $\operatorname{tr}$ & $\operatorname{tr}$ & bdl & $\operatorname{tr}$ & $\operatorname{tr}$ \\
\hline $\mathrm{Fe}$ & 0.2 & bdl & 0.1 & bdl & $\operatorname{tr}$ & $\operatorname{tr}$ & 0.1 & $\operatorname{tr}$ & $\operatorname{tr}$ \\
\hline Mn & bdl & bdl & bdl & bdl & bdl & bdl & bdl & bdl & $\operatorname{tr}$ \\
\hline $\mathrm{Mg}$ & 5.1 & 5.1 & 5.2 & 5.0 & 5.2 & 5.0 & 5.3 & 5.2 & 5.2 \\
\hline $\mathrm{Ca}$ & 0.5 & 1.3 & 0.8 & 1.8 & 1.8 & 1.8 & 1.3 & 1.6 & 1.7 \\
\hline $\mathrm{Na}$ & 1.3 & 0.7 & 1.2 & bdl & bdl & $\mathrm{bdl}$ & 0.5 & 0.2 & 0.3 \\
\hline $\mathbf{K}$ & 0.4 & 0.2 & 0.3 & $\operatorname{tr}$ & bdl & $\operatorname{tr}$ & 0.1 & $\operatorname{tr}$ & 0.1 \\
\hline $\begin{array}{l}\text { Probable } \\
\text { Amphibole }\end{array}$ & winchite & winchite & winchite & tremolite & tremolite & tremolite & $\begin{array}{c}\text { tremolite } \\
\text { or } \\
\text { winchite }\end{array}$ & tremolite & tremolite \\
\hline
\end{tabular}


Table 6. Whole-rock major-element composition of the talc and gabbro rock samples contributed to the DVNP museum study collection. Data was determined by WDXRF analyses (Taggart and Siems, 2002). LOI, loss-on-ignition; total Fe calculated as $\mathrm{Fe}_{2} \mathrm{O}_{3}$.

\begin{tabular}{|c|c|c|c|c|c|c|c|c|c|c|c|c|}
\hline Sample No. & Rock type & $\mathrm{SiO}_{2}$ & $\mathrm{Al}_{2} \mathrm{O}_{3}$ & $\mathrm{Fe}_{2} \mathrm{O}_{3}$ & $\mathrm{MgO}$ & $\mathrm{CaO}$ & $\mathrm{Na}_{2} \mathrm{O}$ & $\mathrm{K}_{2} \mathrm{O}$ & $\mathrm{TiO}_{2}$ & $\boldsymbol{P}_{2} \boldsymbol{O}_{5}$ & $\mathrm{MnO}$ & LOI \\
\hline $30 \mathrm{CDV} 03$ & talc ore & 37.2 & 0.69 & 0.31 & 19.0 & 21.5 & $<0.15$ & 0.67 & 0.02 & $<0.05$ & 0.08 & 19.7 \\
\hline 30DDV03 & talc ore & 54.9 & 0.26 & 0.23 & 27.8 & 6.40 & $<0.15$ & 0.27 & 0.03 & $<0.05$ & 0.03 & 9.39 \\
\hline 36ADV03 & gabbro & 47.6 & 14.5 & 15.2 & 4.55 & 6.34 & 2.39 & 3.28 & 2.92 & 0.57 & 0.20 & 2.05 \\
\hline 36BDV03 & talc schist & 50.9 & 0.61 & 0.36 & 24.0 & 7.76 & $<0.15$ & 0.52 & 0.04 & $<0.05$ & 0.01 & 15.0 \\
\hline $21 \mathrm{CDV} 03$ & talc schist & 52.2 & 0.23 & 0.22 & 25.9 & 9.13 & 0.32 & 0.20 & 0.05 & $<0.05$ & 0.01 & 11.0 \\
\hline 21GDV03 & gabbro & 45.6 & 14.0 & 16.2 & 5.29 & 4.94 & 4.63 & 0.49 & 4.20 & 0.71 & 0.26 & 3.19 \\
\hline 23DDV03 & talc rock & 62.1 & 0.32 & 0.20 & 30.9 & 1.20 & $<0.15$ & 0.09 & 0.03 & $<0.05$ & 0.01 & 4.67 \\
\hline 23EDV03 & talc rock & 54.7 & 0.35 & 0.25 & 26.3 & 9.48 & 0.78 & 0.37 & 0.04 & $<0.05$ & 0.02 & 6.79 \\
\hline
\end{tabular}

\section{REFERENCES CITED}

Campbell, W.J., Blake, R.L., Brown, L.L., Cather, E.E., and Sjoberg, J.J., 1977, Selected silicate minerals and their asbestiform varieties-Mineralogical definitions and identificationcharacterization: U.S. Bureau of Mines Information Circular IC-8751, 56 p.

Evans, J.R., Taylor, G.C., and Rapp, J.S., 1976, Mines and mineral deposits in Death Valley National Monument, California: California Division of Mines and Geology Special Report 125, p. 35-59.

Franklin, R.H., 1965, Grantham mines talc operation: Mining Engineering, v. 17, no. 8, p. 49.

Heaman, L.M., and Grotzinger, J.P., 1992, 1.08 Ga diabase sills in the Pahrump Group, California-Implications for development of the Cordilleran miogeocline: Geology, v. 20, p. 637-640.

Leake, B.E., Woolley, A.R., Arps, C.E.S., Birch, W.D., Gilbert, M.C., Grice, J.D., Hawthorne, F.C., Kato, Akira, Kisch, H.J., Krivovichev, V.G., Linthout, Kees, Laird, Jo, Mandarino, J.A., Maresch, W.V., Nickel, E.H., Rock, N.M.S., Schumacher, J.C., Smith, D.C., Stephenson, N.C.N., Ungaretti, Luciano, Whittaker, E.J.W., and Youzhi, Guo, 1997, Nomenclature of amphiboles-Report of the Subcommittee on Amphiboles of the International Mineralogical Association, Commission on New Minerals and Mineral Names: American Mineralogist, v. 82, p. 1019-1037.

Norman, L.A., Jr., and Stewart, R.M., 1951, Mines and mineral resources of Inyo County: California Journal of Mines and Geology, v. 47, no. 1, p. 113-127.

Occupational Safety and Health Administration, 1992, 29 CFR Parts 1910 and 1926 [Docket No. H-033-d] - Occupational exposure to asbestos, tremolite, anthophyllite and actinolite: Federal Register, v. 57, no. 110 [Monday, June 8, 1992], p. 24310-24331.

Papke, K.G., 1975, The Grantham talc mine, Inyo County, California, in Papke, K.G., Schilling, J.H., Barker, J.M., Wilson, J.L., and Walters, R.A., eds., Guidebook-Las Vegas to Death Valley and return: Nevada Bureau of Mines and Geology Report 26, p. 36-39.

Perkins, R.L., and Harvey, B.W., 1993, Method for the determination of asbestos in bulk building materials: U.S. Environmental Protection Agency Report EPA/600/R-93/116, Office of Research and Development, Washington, D.C., 1 volume (various pagings). 
Taggart, J.E., Jr., and Siems, D.F., 2002, Major element analysis by wavelength dispersive X-ray fluorescence spectrometry, Chapter T, in Taggart, J.E., Jr., ed., Analytical methods for chemical analysis of geologic and other materials, U.S. Geological Survey: U.S. Geological Survey Open-File Report 02-0223. Available on the worldwide web at http://pubs.usgs.gov/of/2002/ofr-02-0223/

Van Gosen, B.S., Lowers, H.A., Sutley, S.J., and Gent, C.A., 2004, Using the geologic setting of talc deposits as an indicator of amphibole asbestos content: Environmental Geology (in press for publication in 2004; accepted for publication November 24, 2003), 43 manuscript pages.

Wright, L.A., 1957, Talc and soapstone, in Wright, L.A., ed., Mineral commodities of California-Geologic occurrence, economic development and utilization of the state's mineral resources: California Division of Mines Bulletin 176, p. 623-634. 1968, Talc deposits of the southern Death Valley-Kingston Range region, California: California Division of Mines Special Report 95, 79 p., 4 plates.

Wright, L.A., Stewart, R.M., Gay, T.E., Jr., and Hazenbush, G.C., 1953, Mines and mineral deposits of San Bernardino County, California: California Journal of Mines and Geology, v. 49 , nos. 1 and 2, p. 197-216. 


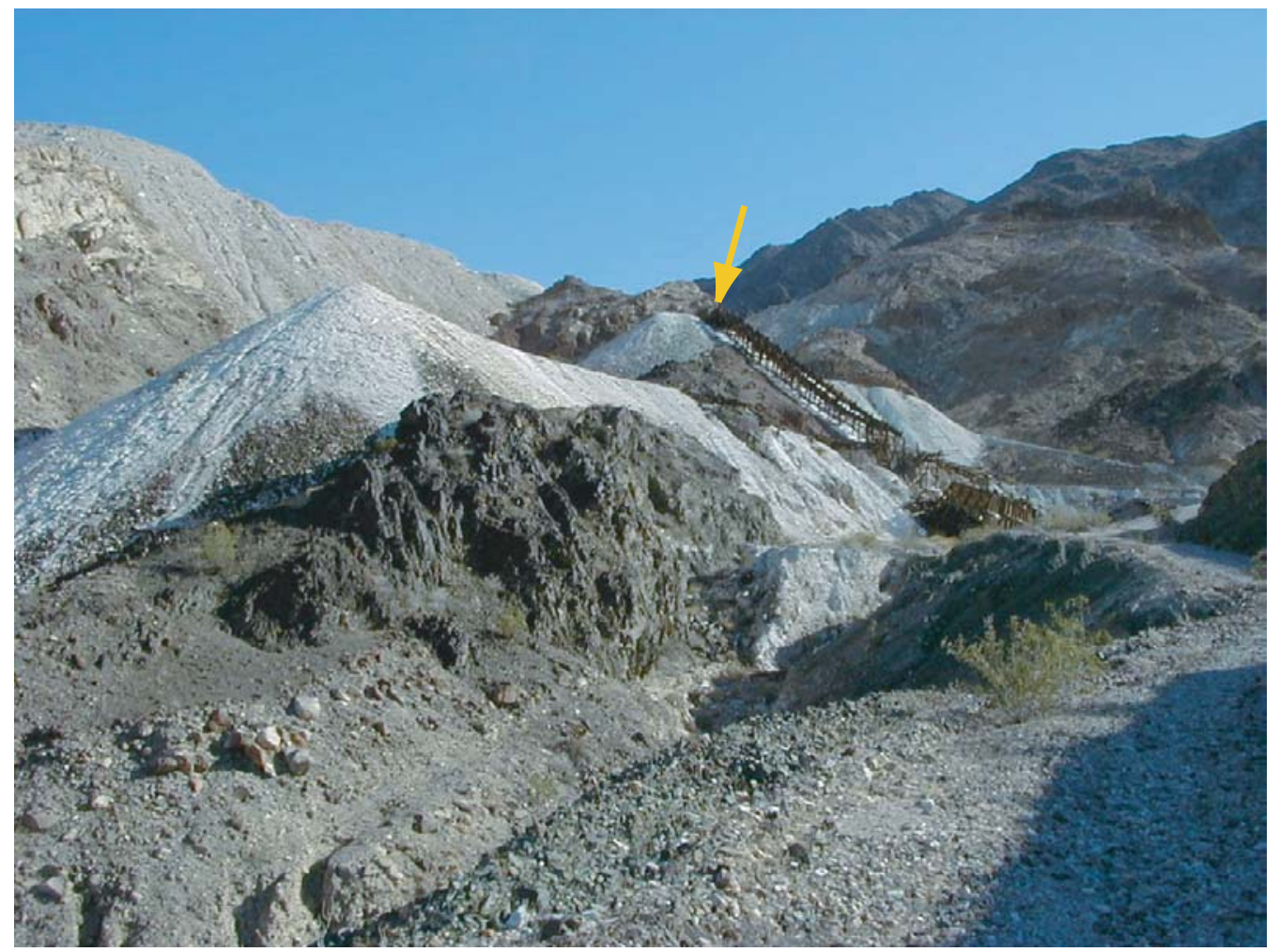

Figure 3. The Moorehouse (Ibex) talc mine in the Ibex Hills, viewed towards the north. Arrow points to the sample site.

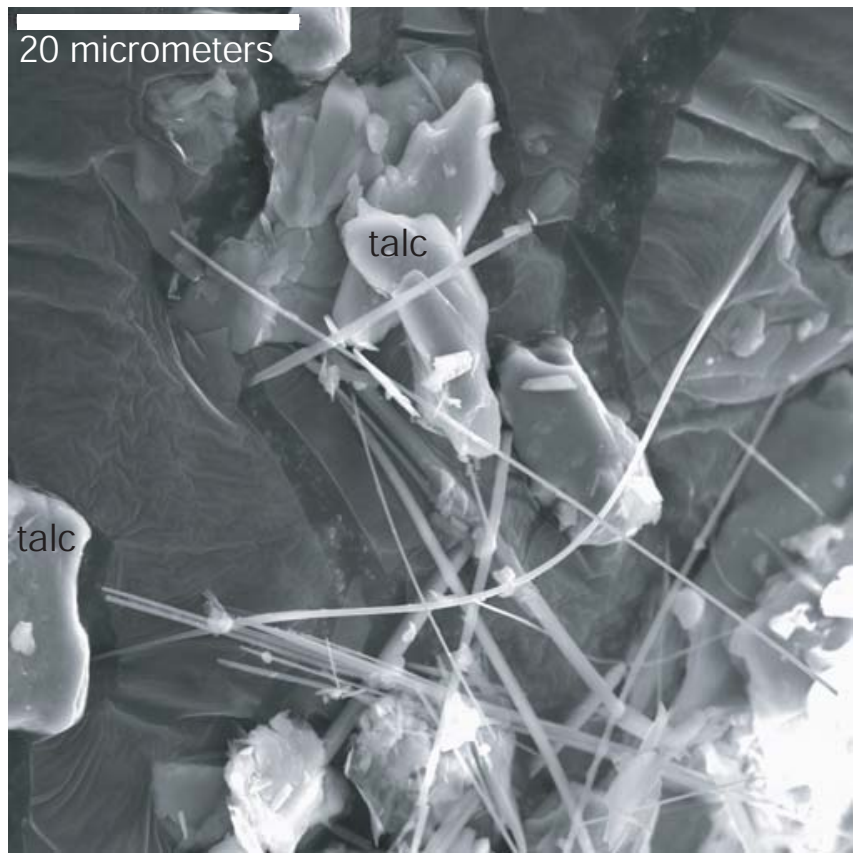

Figure 4. SEM photomicrograph of asbestiform sodic-calcic amphiboles intermingled with platy talc particles in talc ore collected at the Moorehouse mine. 


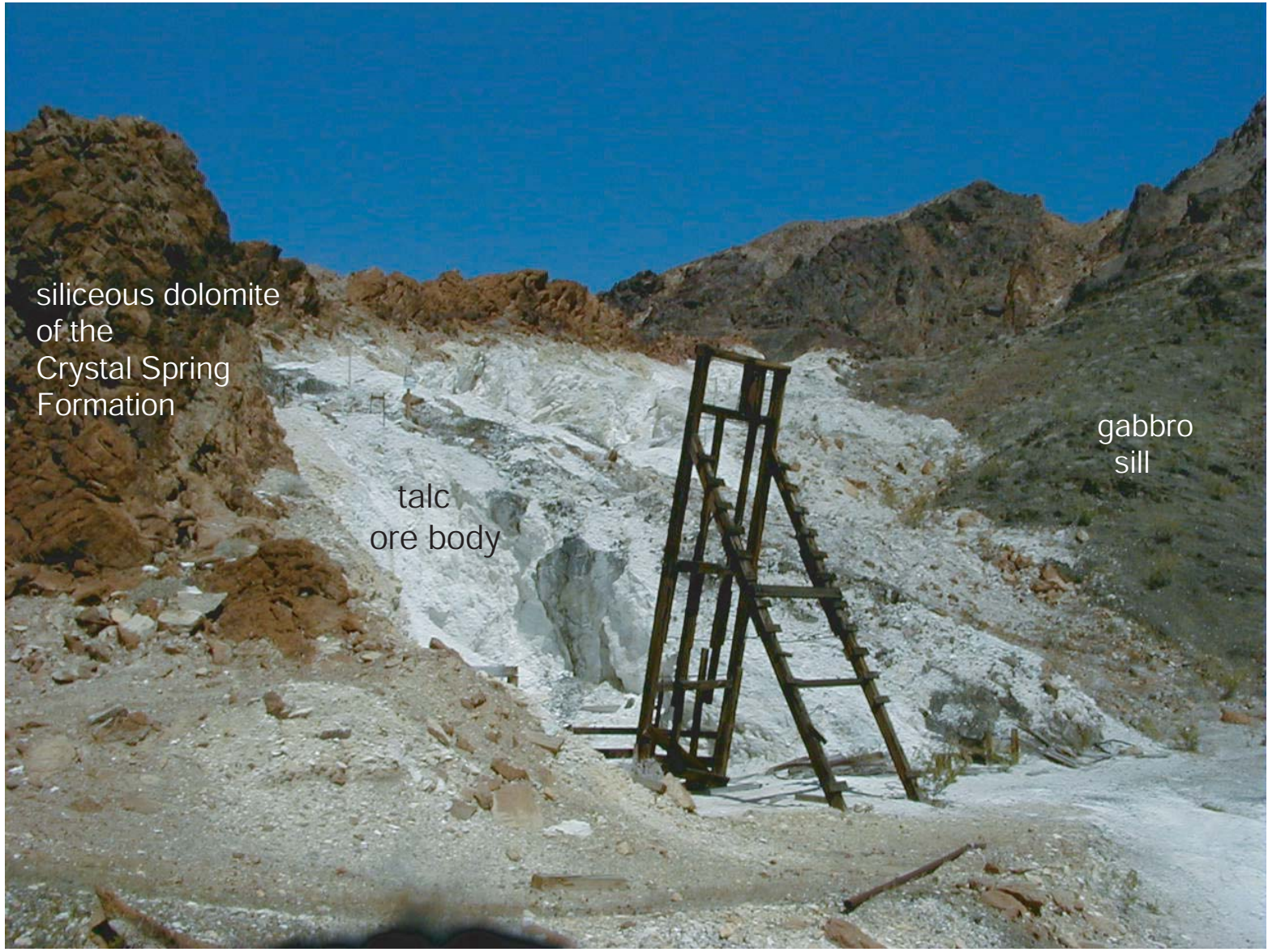

Figure 5. Head frame area of the Pleasanton talc mine, site of samples 36ADV03 (gabbro) and 36BDV03 (talc ore). 


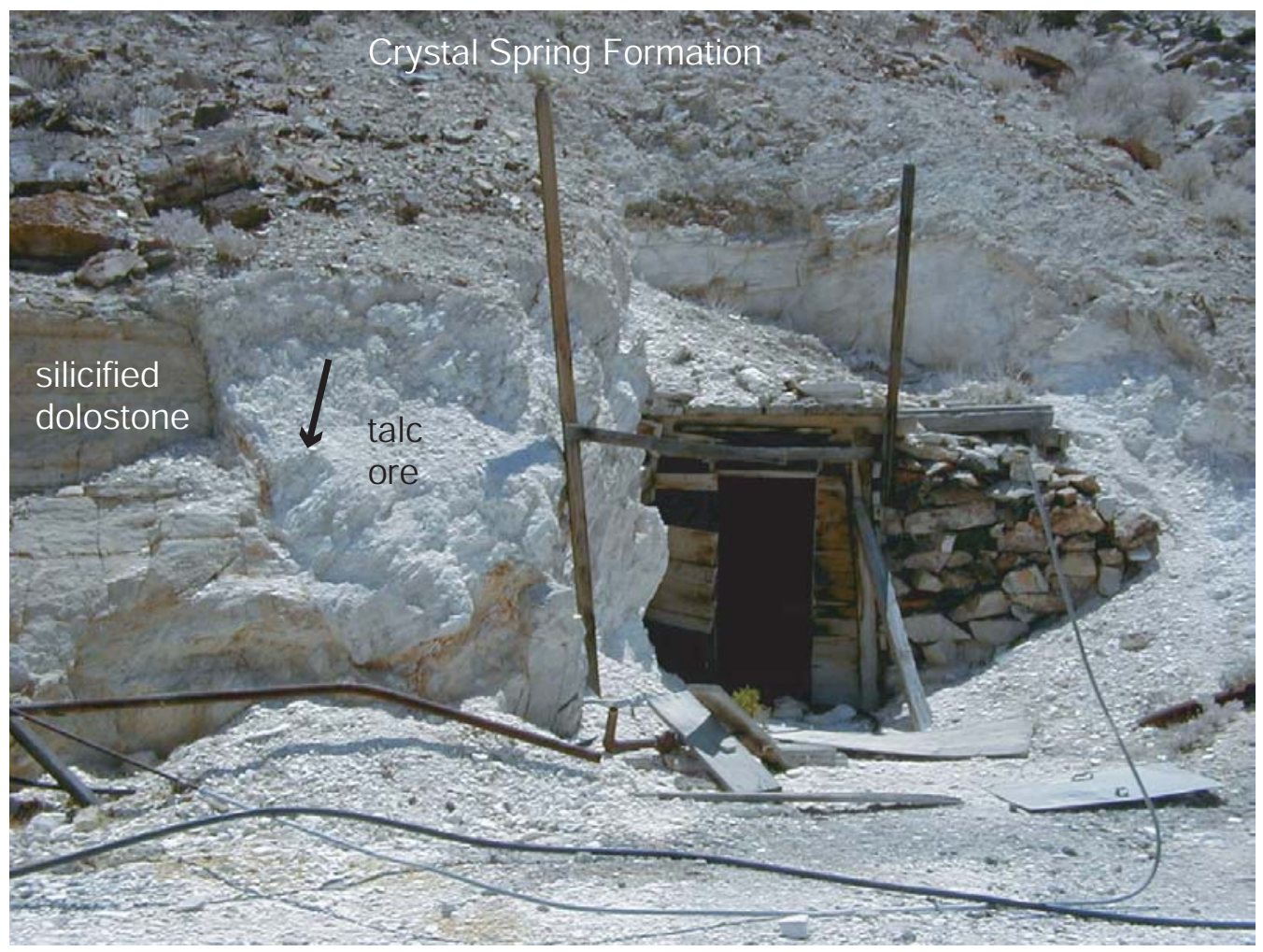

Figure 6. Adit of the Grantham talc mine (Big Talc workings) in Warm Spring Canyon. Talc ore sample 21CDV03 was collected from the area indicated by the arrow.

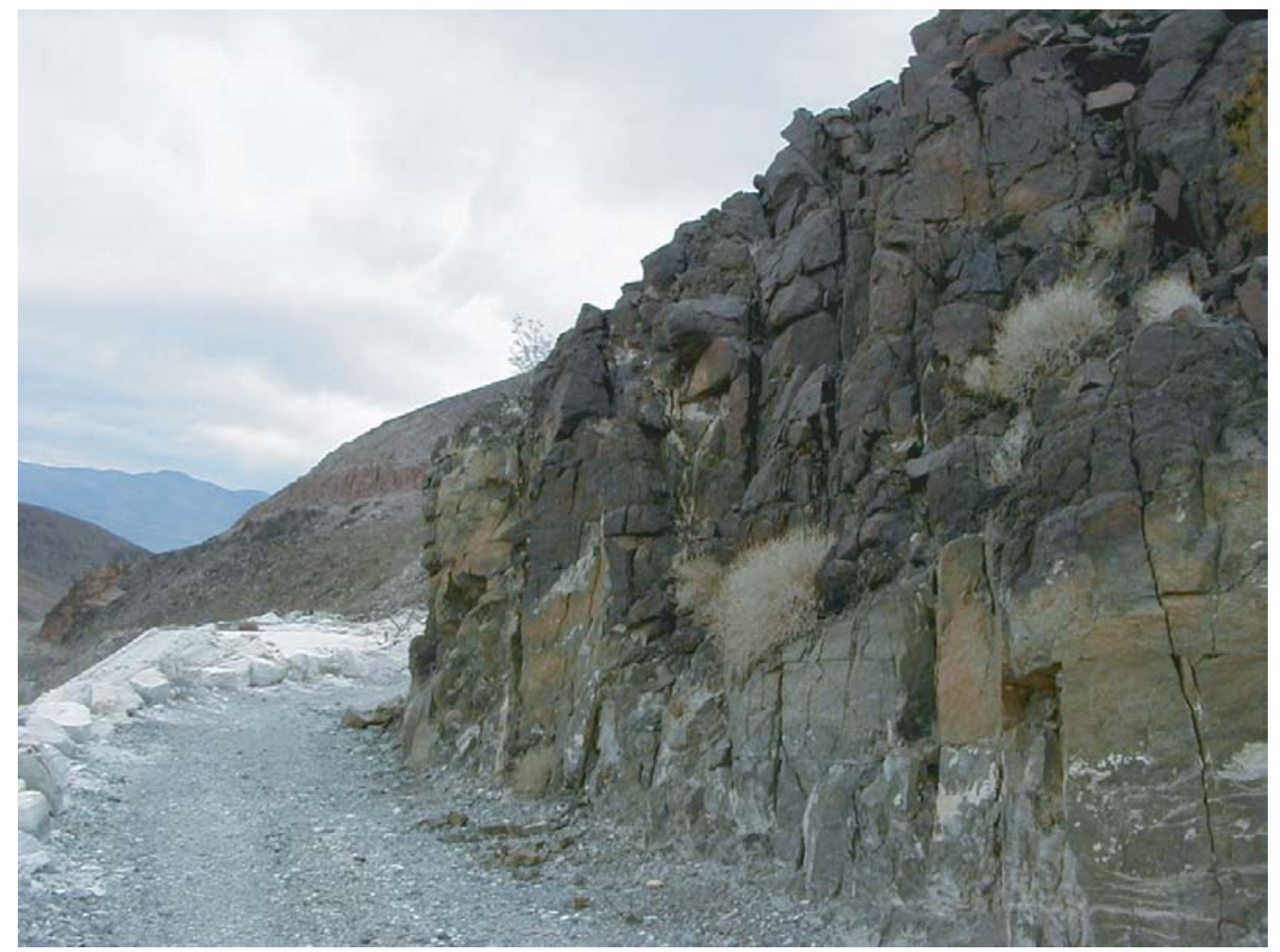

Figure 7. Sill exposed at the Grantham talc mine, site of sample 21GDV03. 


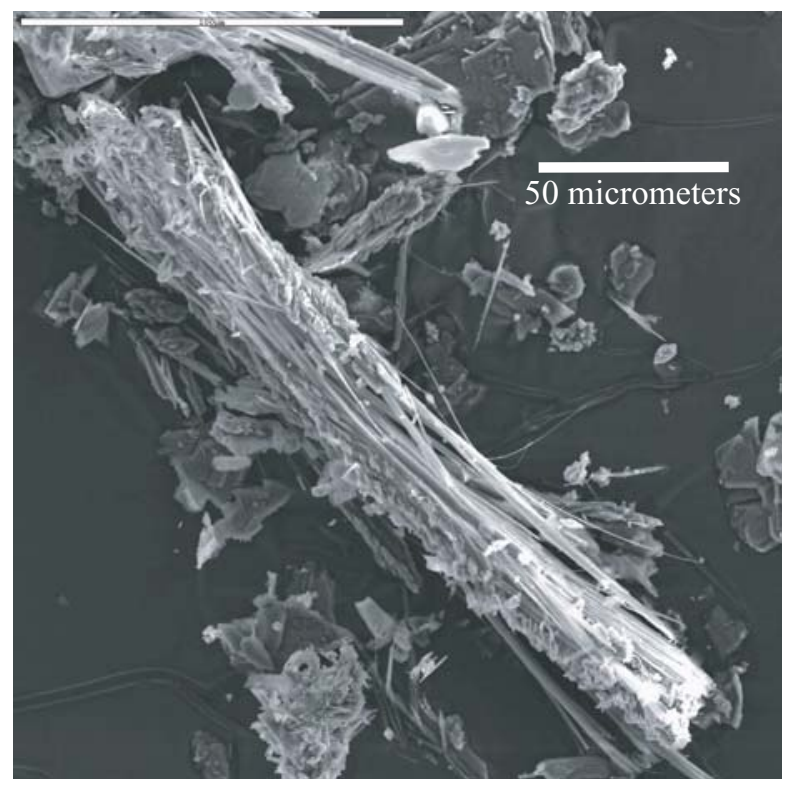

Figure 8. SEM photomicrograph of a fibrous amphibole bundle (likely richterite) in the residue of talc ore from the Grantham mine, Warm Spring Canyon.

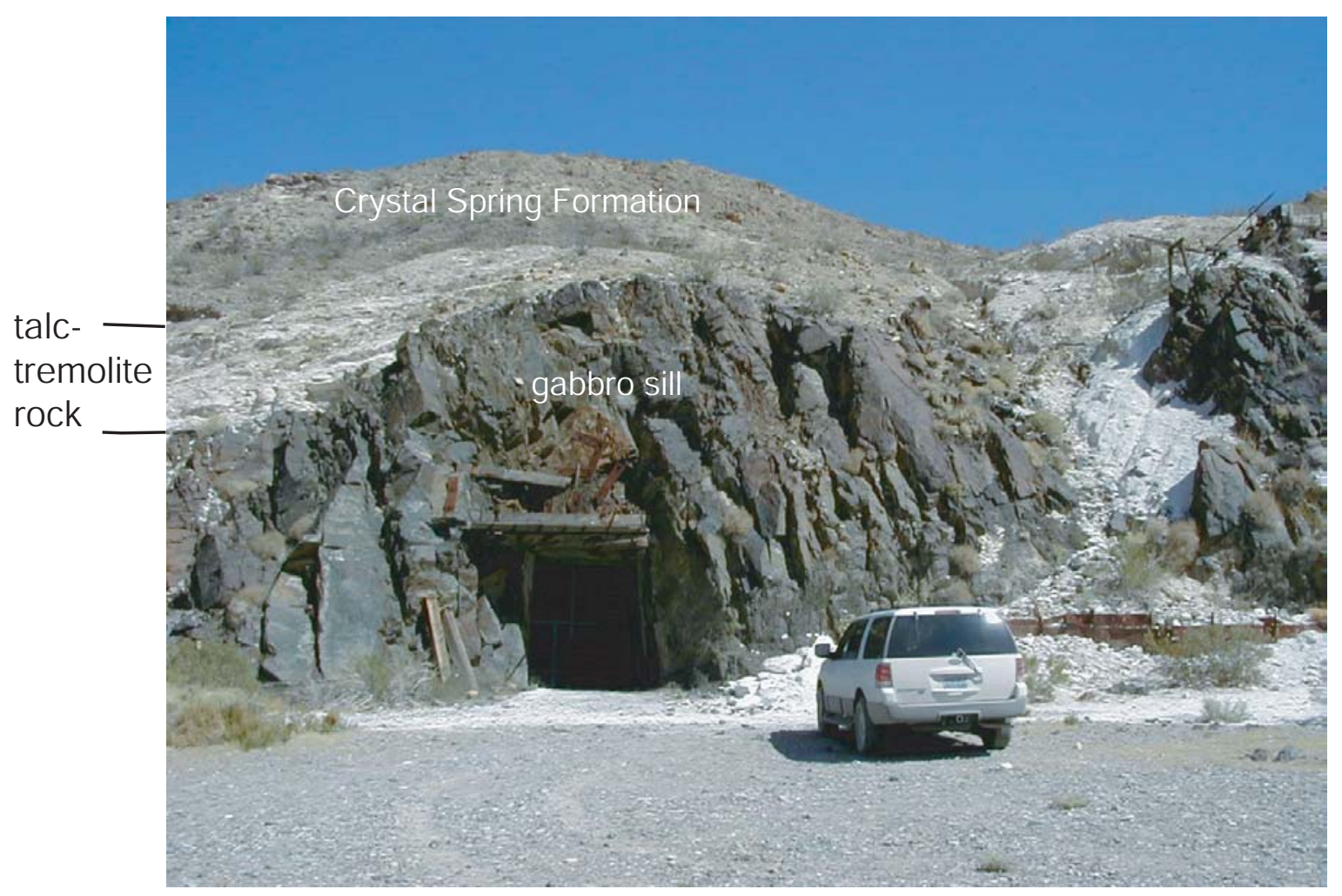

Figure 9. Haulage adit of the White Point workings, near Warm Spring. Talc sample 23EDV03 was picked from the ore dump on the right side of the view. 


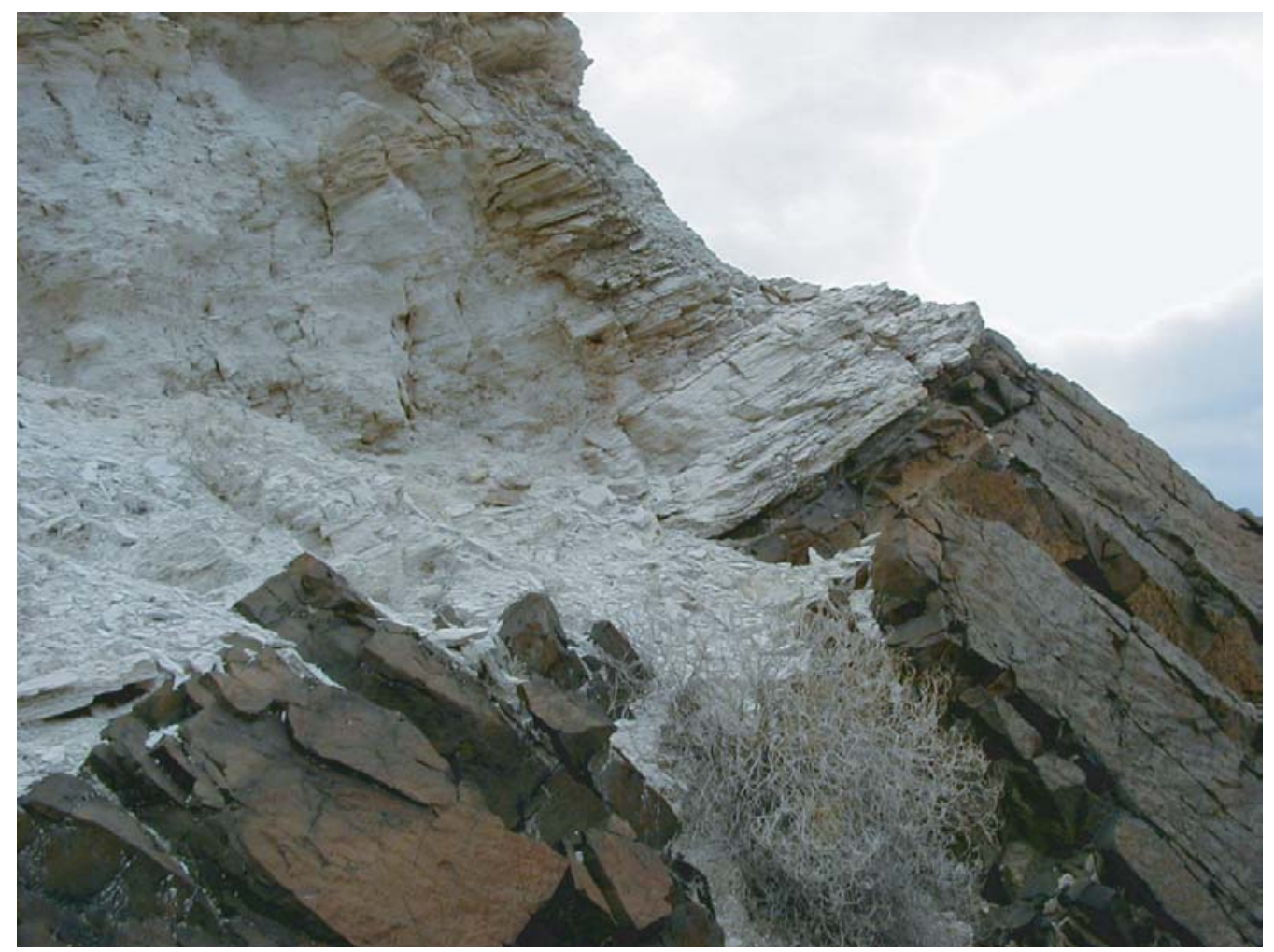

Figure 10. View of the contact between talc-tremolite-rock and the underlying gabbro sill just above the haulage adit of the White Point workings (fig. 9), near Warm Spring.

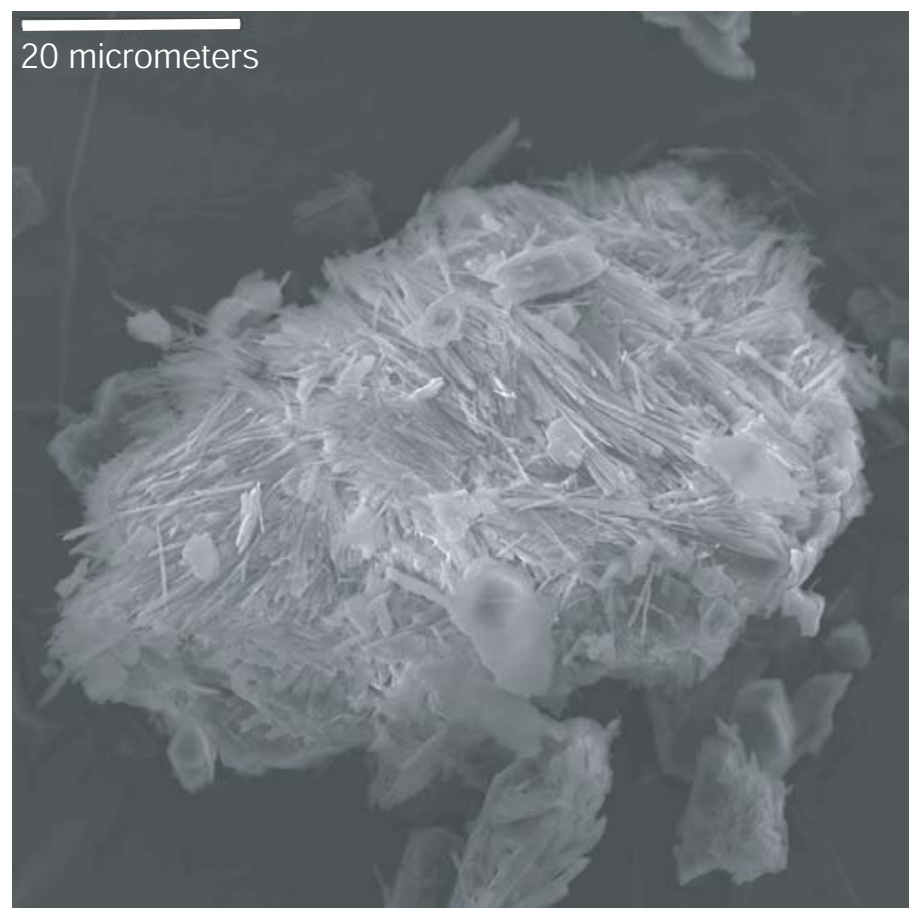

Figure 11. SEM photomicrograph of a bundle of fibrous amphibole (likely tremolite) and platy talc in a talc ore sample from the White Point workings. 